\title{
Menstrual Disorders Among Nursing Students at Al Neelain University, Khartoum State
}

\author{
Aisha Mohammed Adam¹, Hammad Ali Fadlalmola², and Huda Khalafala \\ Mosaad $^{3}$ \\ ${ }^{1}$ Department of Obstetrics and Gynecological Nursing, Faculty of Nursing Sciences, Al Neelain \\ University, Sudan \\ ${ }^{2}$ Department of Community Health Nursing, Nursing College, Taibah University, Saudi Arabia \\ ${ }^{3}$ Faculty of Applied Medical Sciences, Department Nursing, Hafar Albatin University, Saudi Arabia
}

Corresponding Author:

Dr. Hammad Ali Fadlelmola;

Nursing College, Taibah

University, Saudi Arabia

email:

hazzminno345@gmail.com

Received 12 March 2020

Accepted 7 June 2020

Published 30 June 2020

Production and Hosting by

Knowledge E

(c) Aisha Mohammed Adam et al. This article is distributed under the terms of the

Creative Commons

Attribution License, which

permits unrestricted use and

redistribution provided that

the original author and

source are credited.

Editor-in-Chief:

Prof. Mohammad A. M. Ibnouf

\section{Abstract}

Background: Menstrual disorders can severely affect the daily life of young females, particularly the student population, which generates a massive tension that extends to families, but they seldom affect the quality and standard of life.

Objectives: The aim of this study was to determine the morbidity nature of menstrual disorders among nursing students and their effect on students' life activities.

Methods: This study was a descriptive cross-sectional institutional-based study conducted at the Al Neelain University, Faculty of Nursing. Of the 200 students recruited, 149 completed the questionnaire with the responding rate of (74.5\%). Data were collected using a self-administered structured questionnaire.

Results: Of the 149 participants, most were young and in the age range of 18-24 years with a mean age of 21 years. Most students $(74 \%)$ started their menarche at a normal age range of 12-15 years. A relatively high dysmenorrhea (94.0\%) was observed among the participants. More than half of the respondents (55.0\%) had irregular menstruation. Conclusion: The authors concluded that the prevalence and morbidity of dysmenorrhea and menstrual irregularity were high but broadly comparable to those observed in similar developing countries. Therefore, national health policies need to consider the health and educational impact of menstrual disorders on nursing students and develop the plan through a change in students' lifestyle; moreover, school authorities and teachers need to be aware of the problems to provide psychological and academic support.

Keywords: morbidities, dysmenorrhea prevalence, menstrual disorders, nursing students, irregular menstruation

\section{Introduction}

Menstrual disorders are an acute class of problem that young women face during their reproductive years, the most prominent gynecology sickness occurring between 20 and 
seldom affecting the quality and standard of life, as well the social and national economy [2]. Menstruation is an episodic and repeated peeling of endometrium accompanied by loss of blood, it is a regular biological process in females of reproductive age that starts during puberty and may be accompanied by numerous symptoms [3]. It started as assessment means for normal development and the exclusion of irrational situations. The normal menstruation starts at the age of menarche which is ranged between 9 and 15 years [4]. The length of menstrual cycle is 28 to 32 days, duration of flow is 3 to 7 days, and the amount of blood flow per period is $\leq 80 \mathrm{ml}$ [5]. Menstrual disorders are one of the main difficulties facing women worldwide [6], greatly affecting the daily life activities of young women [7], and represents $1 \%$ of women's gynecological appointment [6]. The common types of menstrual disorders are premenstrual syndrome (PMS), dysmenorrheal (painful menstruation), amenorrhea (absence of menstruation), hypomenorrhea (light menstruation), menorrhagia (heavy flow)), metrorrhagia (intermenstrual bleeding), menometrorrhagia (prolonged excessive irregular and more frequent menstruation), polymenorrhea (frequent menstruation), and oligomenorrhea (infrequent menstruation) [8]. While most women experience menstrual discomfort or disruption during their reproductive life, more than $10 \%$ of young women are affected for up to three days due to monthly menstrual disorder and nearly $50 \%$ of them go through painful menstruation frequently. Besides that, abnormal uterine bleeding, which is one of dangerous menstrual disorders, affects about $5-15 \%$ of women of reproductive age [9]. Menstrual disorders are common health problems but with greater burden than any other gynecological complaints [10]. That stated, there is a very scant data on its effects on the health status and quality of life of young females and very little or no attention is given to it in developing countries [5, 11]. In spite of that, the Global Burden of Disease (GBD) approach integrates valuation of morbidity and quality of life in identifying priorities a moment ago [6]. Menstrual disorders, like other parts of sexual and reproductive health are not involved in the GBD estimations [12, 13]. Nevertheless, these morbidities are reported as an important unmet area of reproductive health services for women worldwide including in developing countries [6]. Researches in morbidity and risk factors of menstrual disorders are recommended and anxiously warranted and awaited by many researchers $[6,14]$.

Students are the future of a country, so they must be qualified to become good future leaders and be responsible for improving the health and social and economic status of the country [15]. Menstrual disorders are the common cause of anxiety morbidity in female life and can possibly have significant physical and emotional consequences among students $[7,16]$; moreover the stress of education causes emotional and physical 
discomfort during menstruation and leads to absenteeism from school or college [7], affecting the educational performance and attendance of students and hindering their practical growth [17, 18]. Khadir and colleagues studied menstrual disorders among nursing students and reported that they affected students' academic performance in forms of lectures absence, loss of concentration and understanding, sleeping desire during lectures in addition to affecting their practical performance [17]. Various risk factors have been suggested to be associated with dysmenorrhea such as hormonal imbalance, failure to cope with stress, greater BMI, younger age of menarche, nutritional deficiencies, smoking or exposure to passive smoking, and lack of physical activity. Dysmenorrhea has negative physical and psychological consequences at school, university, leading to absence, academic underachievement, and undermining quality of life [19]. Several studies have been published on the prevalence of dysmenorrhea among female students and especially among female medical students since they are under a lot of academic pressure and have to attend hospitals at difficult times. Most of these studies reported high prevalence of dysmenorrhea among this category, it was found to be more than three quarters among technical secondary schools' girls, and medical college students [20-25]. Although menstrual disorders among students have been studied in various countries $[26,27]$, to the best of our knowledge, very little information on the topic is available in Sudan [28].

\section{Materials and Methods}

\subsection{Study design}

This descriptive cross-sectional institutional-based study was conducted at the Al Neelain University, Faculty of Nursing to determine the nature of morbidity for menstrual disorders among nursing students and their effect on students' educational activities. About 420 female nursing students from different class levels (from level one to level four) registered in the academic year 2018-2019 were included in the study; 25\% of them had menstrual disorders with 5\% error and 95\% confidence interval calculated using internet sample size; 200 sample size was estimated and recruited in clusters to participate according to their proportional representation in the class levels. 


\subsection{Data collection}

A self-administered, structured, questionnaire in English was designed for the study. It was translated to Arabic to ensure the harmony in understanding; then, a pilot study was conducted with 12 students, three students randomly selected from each of the four class levels and were analyzed to determine the tool-reliability. Self-administered questionnaires were distributed to be filled by the nursing students in their break which took them about 15 min to respond.

\subsection{Data analysis}

Data were clean coded and interred in SPSS, version 20, and analyzed using frequencies and percentages. Bivariate analysis of data with a chi-squared test of significance was done where appropriate, $P<0.05$ was considered statistically significant.

\subsection{Ethical considerations}

The study was approved by the Ethical Committeeobtained and all participants gave their consent before participating in the study.

\section{Results}

All students included in this study are young, aged between 18 and 24 years with a mean age of 21 years. Most of them were prepared for menarche (the first onset of menstruation) period by their mothers and teachers as shown in Table 1.

Menarche varies between the populations due to diverse factors such as nutritional, geographical, and environmental conditions. In this study, most of the respondents (74\%) began their menarche at the normal age range of 12-15 years, with a mean age of 13.5 years as shown in Table 2.

With regard to the number of days of the menstrual cycle, we found that in the current study, most respondents had normal menstrual duration of 4 to 7 days. In the present study, more than half of our respondents (55.0\%) had irregular menstruation, while dysmenorrhea was relatively very high (94.0\%) as shown in Table 2.

In this study most respondents reported absence from study for a one to three days due to menstrual problems. Concerning reasons of absentees from the study, the third (32.89\%) of the respondents confirmed very painful period and $13.16 \%$ suffered painful 
TABLE 1: Background characteristics $(n=149)$

\begin{tabular}{|c|c|c|c|c|}
\hline & Frequency & Percentage & Valid Percentage & $\begin{array}{l}\text { Cumulative } \\
\text { Percentage }\end{array}$ \\
\hline \multicolumn{5}{|c|}{ Age group } \\
\hline$<18$ years & 5 & 3.9 & 3.9 & 3.9 \\
\hline $18-20$ years & 82 & 64.1 & 64.1 & 68.0 \\
\hline $21-24$ years & 37 & 28.9 & 28.9 & 96.9 \\
\hline$>24$ years & 4 & 3.1 & 3.1 & 100.0 \\
\hline Total & 128 & 85.0 & 85.0 & \\
\hline Missing value & 21 & 15.0 & 15.0 & \\
\hline Total & 149 & 100.0 & 100.0 & \\
\hline \multicolumn{5}{|c|}{ Student educational level } \\
\hline Level one & 27 & 21.1 & 21.1 & 21.1 \\
\hline Level two & 24 & 18.8 & 18.8 & 39.8 \\
\hline Level three & 42 & 32.8 & 32.8 & 72.7 \\
\hline Level four & 35 & 27.3 & 27.3 & 100.0 \\
\hline Total & 128 & 85.0 & 85.0 & \\
\hline Missing value & 21 & 15.0 & 15.0 & \\
\hline Total & 149 & 100.0 & 100.0 & \\
\hline \multicolumn{5}{|c|}{ Preparation for the menarche (first menstruation) } \\
\hline Yes & 119 & 79.9 & 79.9 & 79.9 \\
\hline No & 30 & 20.1 & 20.1 & 100.0 \\
\hline Total & 149 & 100.0 & 100.0 & \\
\hline \multicolumn{5}{|c|}{ Menstruation information source } \\
\hline $\begin{array}{l}\text { Mother and grand } \\
\text { mother }\end{array}$ & 54 & 36.2 & 45.4 & 45.4 \\
\hline Older sisters & 16 & 10.7 & 13.4 & 58.8 \\
\hline Books and magazines & 5 & 3.4 & 4.2 & 63.0 \\
\hline Mass media & 6 & 4.0 & 5.0 & 68.1 \\
\hline Teachers & 38 & 25.5 & 31.9 & 100.0 \\
\hline Total & 119 & 79.9 & 100.0 & \\
\hline
\end{tabular}

heavy period with vomiting that hindered them from attending their study as shown in Figure 1.

In the present study, correlations between absentness from study and different menstrual problems were presented as shown in Table 3.

\section{Discussion}

While much data concerning menstrual problems are available in the other countries $[26,27,29]$, very scant such data among nursing students are available in Sudan [30]. 
TABLE 2: Menstrual history $(n=149)$

\begin{tabular}{|c|c|c|c|c|}
\hline & Frequency & Percentage & Valid Percentage & $\begin{array}{l}\text { Cumulative } \\
\text { Percentage }\end{array}$ \\
\hline \multicolumn{5}{|c|}{ First menses } \\
\hline$<9$ years old & 0 & 0 & 0 & 0 \\
\hline 9-11 years old & 4 & 2.7 & 2.7 & 2.7 \\
\hline $12-15$ years old & 107 & 71.8 & 72.2 & 74.9 \\
\hline$>15$ years old & 38 & 25.5 & 26.1 & 100.0 \\
\hline Total & 149 & 100.0 & 100.0 & \\
\hline \multicolumn{5}{|c|}{ Menstrual duration } \\
\hline$<3$ days & 11 & 7.4 & 7.4 & 7.4 \\
\hline 4-7 days & 133 & 89.3 & 89.3 & 97.3 \\
\hline$>7$ days & 4 & 2.7 & 2.7 & 100.0 \\
\hline Total & 148 & 99.3 & 100.0 & \\
\hline Missing System & 1 & 0.7 & & \\
\hline Total & 149 & 100.0 & & \\
\hline \multicolumn{5}{|c|}{ The length of the cycle } \\
\hline 28-32 days & 76 & 51.0 & 51.0 & 51.0 \\
\hline$<28$ or $>32$ days & 73 & 49.0 & 49.0 & 100.0 \\
\hline Total & 149 & 100.0 & 100.0 & \\
\hline \multicolumn{5}{|c|}{ Regularity during the last 12 months } \\
\hline Regular & 67 & 45.0 & 45.0 & 45.0 \\
\hline Irregular & 82 & 55.0 & 55.0 & 100.0 \\
\hline Total & 149 & 100.0 & 100.0 & \\
\hline \multicolumn{5}{|c|}{ Presence of dysmenorrhea } \\
\hline There is dysmenorrhea & 140 & 94.0 & 94.0 & 94.0 \\
\hline No dysmenorrhea & 9 & 6.0 & 6.0 & 100.0 \\
\hline Total & 149 & 100.0 & 100.0 & \\
\hline
\end{tabular}

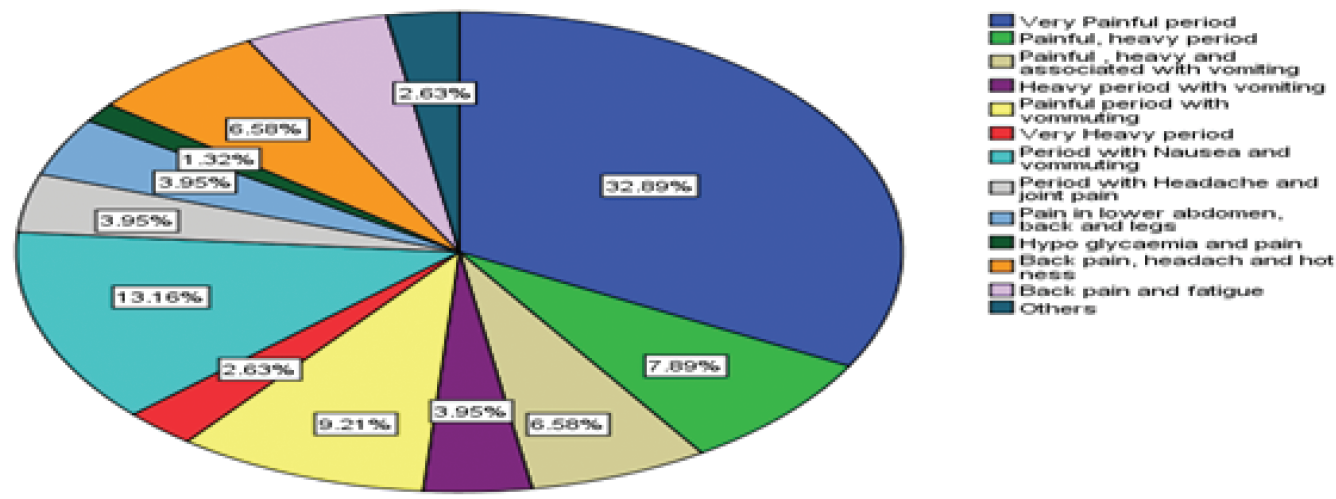

Figure (iii): Events (reasons) of Absentees from study in the faculty

Figure 1: Reasons of absentees from study in faculty 
TABLE 3: Correlations between absentness from study and different menstrual problems $(n=149)$

\begin{tabular}{|c|c|c|c|c|c|c|c|}
\hline & & $\begin{array}{l}\text { Absentees } \\
\text { from study }\end{array}$ & $\begin{array}{c}\text { Age of } \\
\text { Menarche }\end{array}$ & $\begin{array}{c}\text { Menstrual } \\
\text { duration }\end{array}$ & $\begin{array}{l}\text { Length of } \\
\text { the cycle }\end{array}$ & Regularity & $\begin{array}{c}\text { Presence of } \\
\text { Dysmeno- } \\
\text { rrhea }\end{array}$ \\
\hline \multirow[t]{3}{*}{$\begin{array}{l}\text { Absentees } \\
\text { from study }\end{array}$} & $\begin{array}{l}\text { Pearson } \\
\text { Correlation }\end{array}$ & 1 & -0.032 & -0.087 & $-0.185^{*}$ & 0.090 & $0.282^{* *}$ \\
\hline & Sig. (2-tailed) & & 0.697 & 0.293 & 0.024 & 0.274 & 0.001 \\
\hline & $N$ & 149 & 149 & 149 & 149 & 149 & 149 \\
\hline \multirow[t]{3}{*}{$\begin{array}{l}\text { Age of } \\
\text { menarche }\end{array}$} & $\begin{array}{l}\text { Pearson } \\
\text { Correlation }\end{array}$ & -0.032 & 1 & $-0-.136$ & 0.020 & -0.022 & 0.021 \\
\hline & Sig. (2-tailed) & 0.697 & & 0.098 & 0.809 & 0.785 & 0.800 \\
\hline & $N$ & 149 & 149 & 149 & 149 & 149 & 149 \\
\hline \multirow[t]{3}{*}{$\begin{array}{l}\text { Menstrual } \\
\text { duration }\end{array}$} & $\begin{array}{l}\text { Pearson } \\
\text { correlation }\end{array}$ & -0.087 & -0.136 & 1 & 0.110 & 0.070 & $-0.175^{*}$ \\
\hline & Sig. (2-tailed) & 0.293 & 0.098 & & 0.182 & 0.398 & 0.033 \\
\hline & $N$ & 149 & 149 & 149 & 149 & 149 & 149 \\
\hline \multirow[t]{3}{*}{$\begin{array}{l}\text { Length of the } \\
\text { cycle }\end{array}$} & $\begin{array}{l}\text { Pearson } \\
\text { Correlation }\end{array}$ & $-0.185^{*}$ & 0.020 & 0.110 & 1 & 0.075 & -0.129 \\
\hline & Sig. (2-tailed) & 0.024 & 0.809 & 0.182 & & 0.366 & 0.118 \\
\hline & $N$ & 149 & 149 & 149 & 149 & 149 & 149 \\
\hline \multirow[t]{3}{*}{ Regularity } & $\begin{array}{l}\text { Pearson } \\
\text { Correlation }\end{array}$ & 0.090 & -0.022 & 0.070 & 0.075 & 1 & -0.058 \\
\hline & Sig. (2-tailed) & 0.274 & 0.785 & 0.398 & 0.366 & & 0.486 \\
\hline & $N$ & 149 & 149 & 149 & 149 & 149 & 149 \\
\hline \multirow[t]{3}{*}{$\begin{array}{l}\text { Presence of } \\
\text { Dysmenorrhea }\end{array}$} & $\begin{array}{l}\text { Pearson } \\
\text { Correlation }\end{array}$ & $0.282^{* *}$ & 0.021 & $-0.175^{*}$ & -0.129 & -0.058 & 1 \\
\hline & Sig. (2-tailed) & 0.001 & 0.800 & 0.033 & 0.118 & 0.486 & \\
\hline & $N$ & 149 & 149 & 149 & 149 & 149 & 149 \\
\hline \multicolumn{8}{|c|}{${ }^{*}$ Correlation is significant at 0.05 level (2-tailed) } \\
\hline \multicolumn{8}{|c|}{${ }^{* *}$ Correlation is significant at 0.05 level (2-tailed) } \\
\hline
\end{tabular}

So, our study aimed to determine the morbidities of menstrual disorders on nursing students.

The finding of this study is in accordance with that of many other studies that revealed mothers are the main source of information on menarche period for young females aged $[31,32,34]$. This is partially in accordance with others who found that $75 \%$ received this information from their relatives such as mother and sister [35, 36],and differs from many studies that reported school nurse were the first source of information [37], friends were the most important source of information [38]. A study by Singh et al. revealed that the major source of information was media (television, radio) [31].

Menarche is the key of women's physical development during adolescence when they become capable to reproduce; menarche varies between populations according to various factors such as nutritional, geographical, and environmental conditions [39, 40]. 
Most females experience at an age of 9 to 15 year [4]. However, age at menarche has generally declined in most industrialized nations and is reported at 13 years with 0.5 year deviations between countries, the decreased age of menarche is important because of its potential impact on early matureness in girls' behaviors [41]. In our study, most of our respondents (74\%) started their menarche at a normal age range of 12-15 years, with a mean age of 13.5 years, which is comparable with other reports in Khartoum schools girls in Sudan [30], 13.85 year in Egypt [42, 43], 13.40 years in Nigeria [29], and in 13.91 years in Mozambique [26]. However, $25.5 \%$ of our studied students had delayed menarche at age more than 15 years in consistent with the study conducted in Kassala, Eastern Sudan that reported a delayed menarche age [44] contradicting most industrialized nations [41]. This delay in menarche may be due to nutritional, geographical, and environmental conditions $[39,40]$, particularly in Sudan .

In the current study, most participants had normal menstrual duration (4-7 days), supported by the study of Menoufiya University, Egypt [45]. About half of them had cycle with abnormal length either oligo or polymenorrhea, this finding is supported by a study in Lebanon [46], Egypt [45], and Saudi Arabia [46] and disagrees with the study carried out by Neamat et al. in which the majority of respondents had normal menstrual cycle. (31) Polymenorrhea is stated as the top reason for gynecologic visits [5] and may put women at risk of anemia [27, 47, 48]. Moreover, it can result in poor menstrual hygiene and increased risk of infection since many young girls may not be able to afford costly sanitary pads to take care of the extra days especially when they are on campus $[21,49]$. In Sudan, especially in the capital of Khartoum, most nursing students came from various districts.

More than half of the respondents (55.0\%) in this study had irregular menstruation, indeed the prevalence of irregular menstrual cycle is varying within different students' studies. Our finding is observed to be consistent to the finding of the Indian college students the prevalence rate of $57.1 \%$ [50], relatively higher than the findings of the study of school girls in Kassala, Eastern Sudan, Turkey University students, and Saudi nursing students with the prevalence rates of $25.1 \%, 31.2 \%$, and $36.4 \%$, respectively $[44,51,52]$. In contrast, it is relatively lower than the recent finding of the Palestinian study that reached 74.1\% [53]. Irregular menstruation is a factor that increases the rate of emotional and psychological stresses for the female and over prolonged periods can lead to development of infertility, endometrial hyperplasia, and problems due to prolonged anovulation, besides the deterioration in the quality of life and being the leading cause for clinical visits $[54,55]$. 
Dysmenorrhea was relatively high (94.0\%) in our respondents; this finding is in line and fits within the published reported values from developing and developed countries as in Saudi, Egypt, and Oman nursing students which is about 94.0\% [31, 43, 52, 56 58].However, it is relatively higher than found in the studies in India, Kassal Eastern Sudan, Palestine, Ethiopia, Australia, and Nigeria that reached $87.87 \%, 85.1 \%$, 80\%, and (76\%), respectively $[44,53,59-62]$.

The literature has suggested various risk factors for dysmenorrhea hormonal imbalance, namely, failure to cope with stress, greater BMI, younger age of menarche, nutritional deficiencies, smoking or exposure to passive smoking, and lack of physical activity $[47,63,64]$. Since our respondents were under a lot of academic pressure and had to attend the clinical training and practice in the hospital which is more stressful for them; in addition to that most of them are living away from their families that can expose them to nutritional deficiencies and possible lack of activities. Our finding is answerable and supported by many studies that reported high prevalence of dysmenorrhea among medical students [20-22].

In this study, most respondents reported absence from the study for a period ranging between one and three days due to menstrual problems; this is similar to the findings of the studies of Kassala, Eastern Sudan, Kingdom of Saudi Arabia, Amhara- Ethiopia, Nigeria, and India [5, 44, 52, 60, 65-68]. In contrasts, our finding is relatively higher compared to the Egyptian and Australian findings [31, 69]. Our respondents' absenteeism seems to be due to the high prevalence of dysmenorrhea which is declared as having negative physical and psychological consequences leading to school/university absence, academic underachievement, and undermined quality of life $[47,63,70]$.The respondents' absence from study in the current research is significantly associated with the presence of dysmenorrhea and the length of the cycle, similar to the finding of a study in Nigeria [67].

Concerning reasons of absentees from the study, one-third $(32.89 \%)$ of the respondents confirmed very painful period, and $14.47 \%$ suffered painful heavy period accompanied with vomiting, hindering them from attending their study. This finding is supported by the literature that evident painful menses is an important health problem in university female students and has a negative effect on their academic performance [66].

\section{Conclusion}

The authors conclude that the prevalence and morbidity of dysmenorrhea and menstrual irregularity were high but broadly comparable to those observed in similar developing 
countries. Therefore, national health policies need to consider the health and educational impact of menstrual disorders on nursing students and develop the plan through a change in students' lifestyle. Moreover, school authorities and teachers need to be aware of the problems to provide psychological and academic support. Besides, health authorities who are working in the university's student clinic should design a health education program to organize the college community to adjust students' behaviors. Further research into risk factors for menstrual disorders and their morbidity is recommended.

\section{Acknowledgments}

The authors are thankful to all nursing students who participated in this research and convey great thanks to the Faculty of Nursing, Al Neelain University.

\section{Funding}

Authors declared that no funding was provided for this study.

\section{Conflict of Interest}

Authors declare that there is no conflict of interest.

\section{Availability of data and material}

The study materials are available with the corresponding author on request.

\section{References}

[1] Burnett, M. A., Antao, V., Black, A. (2005). Prevalence of primery dysmenorrhea in Canada. Journal of Obstetrics and Gynaecology Canada, vol. 27, no. 8, pp. 765-770.

[2] Nooh, A. M. (2015). Menstrual disorders among Zagazig University students, Zagazig, Egypt. Middle East Fertility Society Journal, vol. 20, pp. 198-203.

[3] Moronkola, O. A. and Uzuegbu. V. U. (2006). Menstruation: symptoms, management and attitude of female nursing students in Ibadan, Nigeria. African Journal of Reproductive Health, vol. 10: 84-89. 
[4] Yermachenko, A. and Dvornyk, D. (2014). Nongenatic determinants of age at menarche: a systematic review. BiomMed Research Intenational, vol. 23, pp. 1-14.

[5] Esimai, O. A. and Omoniyi Esan, G. O. (2010). Awareness of menstrual abnormality amongst college students in urban area of lle-lfe, Osun State, Nigeria. Indian Journal of Community Medicine, vol. 35, no. 1, p. 63.

[6] Harlow, S. D. and Campbell, O. M. R. (2000). Menstrual dysfunction: a missed opportunity for improving reproductive health in developing countries. Reproductive Health Matters, vol. 8, pp. 142-147.

[7] Eyitope, O. A. and Bamidele, J. O. (2014). Prevelance of menstrual disporders among adolescent girl in Osogbo, South Western Nigeria. International Journal of Adolescent Medicine and Health, vol. 26, no. 1, pp. 101-106.

[8] Ekpenyong, K. J. D., Davis, K. J., Akpan, U. P., et al. (2011). Academic stress and menstrual disorders among female undergraduates in Uyo, South Eastern Nigeria the need for health education. Nigerian Journal of Physiological Sciences, vol. 26, pp. 193-198.

[9] Pullon, S. R. J. and Sparro, M. (1988). Prevalence of dysmenorrhoea in Wellington women. The New Zealand Medical Journal, vol. 101, no. 839, pp. 52-54.

[10] Patel, V. T. V., Sahasrabhojanee, M., Gupte, S., et al. (2006). The burden and determinants of dysmenorrhea: a population-based survey of 2262 women in Goa, India. BJOG, vol. 113, pp. 453-463.

[11] El Gilany, A., Badawi, K. and El Fedawy, S. (2005). Epidemiology of dysmenorrhoea among adolescent students in Mansoura, Egypt. Eastern Mediterranean Health Journal, vol. 11, no. 1/2, pp. 155-163.

[12] AbouZahr, C. V. J. (2000). Assessing the burden of sexual and reproductive ill-health: questions regarding the use of disability adjusted life years. Bulletin of the World Health Organization, vol. 78, pp. 655-666.

[13] Murray, C. J. L., Lopez, A. D., and WHO. (1998). Health Dimensions of Sex and Reproduction. Boston: Harvard University Press.

[14] Harlow, S. D., Campbell, O. M. R. (2004). Epidemiology of menstrual disorders in developing countries: a systematic review. BJOG, vol. 111, no. 1, pp. 6-16.

[15] Alos, S. B., Caranto, L. C., and David, J. J. T. (2015). Factors affecting the academic performance of the student nurses of BSU. International Journal of Nursing Sciences, vol. 5, no. 2, pp. 60-65.

[16] Gujarathi, J., Jani, D., and Murthi, A. (2014). Prevalance of menstrual disorders in hostellers and its effect on education-a cross sectional study. World Journal of Pharmaceutical Research, vol. 3, no. 2, pp. 4060-4065. 
[17] Elnagar, R. R., Elmashed, H. A. M. and Haasan Kheder, N. F. (2017). Menstrual disorders: incidence and its effect on students' academic performance. International Journal of Nursing Didactics, vol. 7, no. 03, pp. 27-37.

[18] Fadlalmola, H. A. and Elkareem, E. M. A. (2020). Impact of an educational program on knowledge and quality of life among hemodialysis patients in Khartoum state. International Journal of Africa Nursing Sciences, vol. 12, 100205.

[19] Fernández-Martínez, E., Onieva-Zafra, M. D., Abreu-Sánchez, A., et al. (2020). Absenteeism during menstruation among nursing students in Spain. International Journal of Environmental Research and Public Health, vol. 17, no. 1, p. 53.

[20] Ibrahim, N. K., AlGhamdi, M. S., Al-Shaibani, A. N., et al. (2015) Dysmenorrhea among female medical students in king abdulaziz university: prevalence, predictors and outcome. Pakistan Journal of Medical Sciences, vol. 31, no. 6, pp. 1312-1317.

[21] Charu, S., Ray, A., Sujoy, R., et al. (2012). Menstrual characteristics' and 'prevalence and effects of dysmenorrhea' on quality of life of medical students. International Journal of Collaborative Research on Internal Medicine and Public Health, vol. 4, no. 4, pp. 276-294.

[22] Jayanthi, B. Anuradha, H. V. (2014). Self-medication practice for dysmenorrhoea in medical, paramedical and non-medical students. International Journal of Pharmaceutical Sciences Review and Research, vol. 27, no. 1, pp. 141-145.

[23] El-Said Mansour, S. and El-Sayed Mohamed, H. (2013). The effect of dysmenorrhea on quality of life of technical secondary schools girls. Medical Journal of Cairo University, vol. 81, no. 2, pp. 83-89.

[24] Bakr IE-E, H. S. (2010). Prevalence of premenstrual syndrome and the effect of its severity on the quality of life among medical students. The Egyptian Journal of Community Medicine, vol. 28, no. 2, pp. 19-30.

[25] Seedhom, A. E., Mohammed, E. S., and Mahfouz, E. M. (2013). Life Style Factors Associated with Premenstrual Syndrome among El-Minia University Students, Egypt. International Scholarly Research Notices, vol. 2013, article ID 617123.

[26] Padez, C. (2003). Age at menarche of schoolgirls in Maputo Mozambique. Annals of Human Biology, vol. 30, no. 4, 487-495.

[27] Rebacz, E. (2009). Age at menarche in schoolgirls from Tanzania in light of socioeconomic and sociodemographic conditioning. Collegium Antropologicum, vol. 33 , no. 1, pp. 23-29.

[28] Fadlalmola, H. A. and Elkareem, E. M. A. (2020). Impact of an educational program on knowledge and quality of life among hemodialysis patients in Khartoum state. International Journal of Africa Nursing Sciences, vol. 12, no. 2, p. 100205. 
[29] Okusanya, B. O., Garba, K. K. D., Okome, G. B. O., et al. (2009). Menstrual pain and associated factors amongst undergraduates of Ambrose Alli University, Ekpoma, Edo State, Nigeria. Nigerian Journal of Medicine, vol. 18, no. 4, pp. 409-412.

[30] Attallah, N. L., Matta, W. M., and El-Mankoushi, M. (1983). Age at menarche of schoolgirls in Khrtoum. Annals of Human Biology, vol. 10, no. 2, pp. 185-188.

[31] Neamat, A., Abd El-Hameed, M. S. M., Ahmed, N. H., et al. (2011). Assessment of dysmenorrhea and menstrual hygiene practices among adolescent girls in some nursing schools at EL-Minia Governorate, Egypt. Journal of American Science., vol. 7, no. 9.

[32] Ersog, B. B. C., Gunay, T., Onag, A., et al. (2004). Effects of different socioeconomic conditions on menarche in Turkish female students. Early Human Development, vol. 76, pp. 115-125.

[33] Kari, S. Dangol, S., Shrestha S, et al. (2005). Building demand for RH awareness among adolescent girls in conflict affected districts of Nepal. Kathmandu, Nepal: Center For Research on Environment Health And Population Activities (Crehpa).

[34] Tiwari, H., Oza, U. N., and Tiwari, R. (2006). Knowledge, attitudes and beliefs about menarche of adolescent girls in Anand district, Gujarat. Eastern Mediterranean Health Journal, vol. 12, pp. 428-433.

[35] Poureslami, M. and Osati-Ashtiani, F. (2002). Attitudes of female adolescents about dysmenorrhea and menstrual hygiene in Tehran suburbs. Archives of Iranian Medicine, vol. 5, no. 4, p. 219.

[36] Mohammad Taghi Ayatollahi, S., Dowlatabadi, E, and Ayatollahi, S. A. R. (2002). Age at menarche in Iran. Annals of Human Biology. vol. 29, no. 4, pp. 355-362.

[37] Dhingra, R., Kumar, A., and Kour, M. (2009). Knowledge and Practices related to menstruation among tribal (gujjar) adolescent girls. Ethno-Medicine, vol. 3, no. 1, pp. $43-48$.

[38] Singh, A. J. (2006). Place of menstruation in the reproductive lives of women of rural north India. Indian Journal of Community Medicine, vol. 31, no. 1, pp. 10-14.

[39] Thomas, K. D., Okonofua, F. E., and Chiboka, O. (1990). A study of the menstrual patterns of adolescents in Ile-Ife, Nigeria. International Journal of Gynecology \& Obstetrics, vol. 33, pp. 1-4.

[40] Kaplowitz, P. (2006). Pubertal development in girls: secular trends. Current Opinion in Obstetrics and Gynecology, vol. 18, no. 5, pp. 487-491.

[41] Anthony, D. O., Bergeman, C. S., Bisconti, T. L. et al. (2006). Psychological resilience, positive emotin, and successful adaptation to stress in later life. Journal of Personality and Social Psychology, vol. 91, no. 4, pp. 730-749. 
[42] Titilayo, A., Agunbiade, O. M., Banjo, O. et al. (2009). Menstrual discomfort and its influence on daily academic. Tanzania Journal of Health, vol. 11, no. 4, pp. 181-188.

[43] Abdelmoty, H. I., Youssef, M. A., Abdallah, S. (2015). Menstrual patterns and disorders among secondary school adolescents in Egypt. a cross-sectional survey. BMC Women's Health, vol. 15, no. 70, pp. 1-6.

[44] Abdel Aziem, A., Ali, A. A., and Rayis, D. (2011). Age at menarche and menstrual cycle pattern among schoolgirls in Kassala in eastern Sudan. Journal of Public Health and Epidemiology, vol. 3, no. 3, pp. 111-114.

[45] Eittah, H. F. A. (2014). Effect of breakfast skipping on young females' menstruation. Health Science Journal, vol. 8, no. 4, pp. 469-484.

[46] Karout, N. (2015). Prevalence and pattern of menstrual problems and relationship with some factors among Saudi nursing students. Journal of Nursing Education and Practice, vol. 5, no. 12, pp. 1-8.

[47] Kadir, R. A., Edlund, M., and Von Mackensen, S. (2010). The impact of menstrual disorders on quality of life in women with inherited bleeding diorders. Hemophilia, vol. 16 , no. 5, pp. 832-839.

[48] Palep-Singh, M. and Prentice, A. (2007). Epidemiology of abnormal uterine bleeding. Best Practice \& Research Clinical Obstetrics \& Gynaecology, vol. 21, no. 6, pp. 887890.

[49] Gumanga, S. K. and Kwame-Aryee, R. A. (2012). Menstrual characteristics in some adolescent girls in Accra, Ghana. Ghana Medical Journal, vol. 46, no. 1, pp. 3-7.

[50] Mohite, R. (2013). Correlates of the menstrual problems among rural college students of Satara district. Al Ameen Journal of Medical Science, vol. 6, no. 3, pp. 213-218.

[51] Cakir, M., Mungan, I., Karakas, T. (2007). Menstrual pattern and common menstrul disorders among university students in Turkey. Pediatrics International, vol. 49, pp. 938-942.

[52] Karout, N. (2015). Prevalence and pattern of menstrual problems and relationship with some factors among Saudi nursing students. Journal of Nursing Education and Practice, vol. 5, no. 12.

[53] Abu Helwa, H. A., Mitaeb, A. A., Al-Hamshri, S., et al. (2018). Prevalence of dysmenorrhea and predictors of its pain intensity among Palestinian female university students. BMC Women's Health, vol. 18, p. 18.

[54] Barron, M. L., Cook, C. A., Homan, S. M., et al. (2008). Associations between psychiatric disorders and menstrual cycle characteristics. Archives of Psychiatric Nursing, vol. 22, no. 5, pp. 254-265. 
[55] Sood, M., s.krishnapillai, A., Nikmat, A. W. (2012). Poor correlation of stress levels and menstrual patterns among medical students. Journal of Asian Behavioural Studies, vol. 2, no. 7, pp. 60-66.

[56] Elnagar, R. R., M Elmashed, H. A., Fikry Haasan Kheder, N. (2017). Menstrual disorders: incidence and its effect on students' academic performance. International Journal of Nursing Didactics, vol. 7, no. 3, 27-37.

[57] Shehata, N. A. A., Arafa, A. E., Abd El Wahed, H. A., et al. (2018). Epidemiology of dysmenorrhea among university students in Egypt. International Journal of Women's Health and Wellness, vol. 4, no. 1, p. 73.

[58] Al-Kindi, R. and Al-Bulushi, A. (2011). Prevalence and impact of Dysmenorrhea among Omani High School students. Sultan Qaboos University Medical Journal, vol. 11, no. 4, pp. 485-491.

[59] George, A. and Bhaduri, A. (2002). Dysmenorrhea among adolescent girls-symptoms experienced during menstruation. Journal of Health Promotion Education, vol. 17, no. 4, pp. 23-34.

[60] Shiferaw, M. T., Wubshet, M., and Tegabu, D. (2014). Menstrual problems and associated factors among students of Bahir Dar University, Amhara National Regional State, Ethiopia: a cross-sectional survey. The Pan African Medical Journal, vol. 17, p. 246.

[61] De Sanctis, V., Elsedfy, H., Soliman, N. A., et al. (2016). Dysmenorrhea in adolescents and young adults: a review in different countries. Acta BioMedica, vol. 87, no. 1, p. 34.

[62] Olowokere, A. E., Oginni, M. O., Olajubu, A. O., et al. (2014). Menstrual disorders: The implications on health and academic activities of female undergraduates in a federal university in Nigeria. Journal of Nursing Education and Practice, vol. 4, no. 5, pp. 126-135.

[63] French, L. (2005). Dysmenorrhea. American Family Physician, vol. 71, pp. 285-291

[64] Ballagh, S. A. and Heyl, A. (2008). Communicating with women about menstrual cycle symptoms. Journal of Reproductive Medicine, vol. 53, pp. 837-846.

[65] Hasanein, N. and Mohamed Diab, S. (2015). Menstrual disorders and hygienic self care practices among adolescent girls in preparatory year at Al-Jouf University. IOSR Journal of Nursing and Health Science, vol. 4, no. 3.

[66] Derseh, B. T., Afessa, N., Temesgen, M., et al. (2017). Prevalence of Dysmenorrhea and its effects on school performance: a cross-sectional study. Journal of Women's Health Care, vol. 6, no. 2, p. 361. 
[67] Titilayo, A., Agunbiade, O. M., Banjo, O., et al. (2009). Menstrual discomfort and its influence on daily academic activities and psychosocial relationship among undergraduate female students in Nigeria. Tanzania Journal of Health Research, vol. 11, no. 4, pp. 181-188.

[68] Dambhare, D. G., Wagh, S. V., and Dudhe, J. Y. (2012). Age at menarche and menstrual cycle pattern among school adolescent girls in Central India. Global Journal of Health Science, vol. 4, no. 1, pp. 105-111.

[69] Parker, M. A., Sneddon, A. E., and Arbon, P. (2010). The menstrual disorder of teenagers (MDOT) study: determining typical menstrual patterns and menstrual disturbance in a large population-based study of Australian teenagers. BJOG, vol. 117, no. 2, pp. 185-192.

[70] Ballagh, S. A. and Heyl, A. (2008). Communicating with women about menstrual cycle symptoms. The Journal of Reproductive Medicine, vol. 53, no. 11, pp. 837-846. 